International Journal of Instruction e-ISSN: 1308-1470 • www.e-iji.net

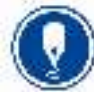

Article submission code: 20200521151028
Received: 21/05/2020

Revision: 14/12/2020
July $2021 \bullet$ Vol.14, No.3

p-ISSN: 1694-609X

pp. 287-308

Accepted: 06/01/2021

OnlineFirst: 06/05/2021

\title{
Stakeholders Evaluation on Educational Quality of Higher Education
}

\section{Munirul Abidin}

Dr., Islamic Education Faculty, Universitas Islam Negeri Maulana Malik Ibrahim

Malang, Indonesia, munirul@bio.uin-malang.ac.id

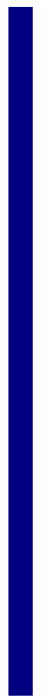

Knowing the stakeholder's perception of educational quality is essential for Higher Education (HE) institutions because it reflects the market acceptance of its products. The study aims to analyze stakeholders' satisfaction with HE's quality through the performance of its graduates. Data collected through surveys to 258 customers in 15 educational institutions and analyzed quantitatively. The researcher used the Customer Satisfaction Index (CSI) and Importance Performance Analysis (IPA) to explain the gap between stakeholders' satisfaction and alumni performance. This research found that customer satisfaction on the quality of graduates of researched university falls within the range of 'satisfied' categories and quality of graduates' performance, or skill has been rated 'good' by Customer. However, there are still three competencies considered 'sufficient' by Customers. This study also finds a gap between customer satisfaction and graduates' performance, which the mean reaches -1.16 . The biggest gaps are in the logical, analytical, and problem-solving competencies with the gap score -1.56 , and innovation and creativity competencies with the gap score -1.59 . This research implies higher education institutions to improve these competencies that are considered lacking through the learning process and other appropriate programs to meet customer satisfaction.

Keywords: educational quality, customer, stakeholder, islamic higher education, satisfaction, performance

\section{INTRODUCTION}

Rapid world changes provide many challenges for HE (Ansell, 2008). As a graduate producer, HE faced many problems to produce human resources who have several abilities, expertise, and knowledge to be in line with the needs of the work world in the 21st century (Garzone \& Viezzi, 2002; Much et al., 2014; Scott, 2000; Teichler, 1999). Besides, many HE graduates can't be absorbed in the world of work (Harvey, 2000). Today more than 600,000 graduates of Indonesian HE unemployed (Mada \& Ashar, 2015; Maryati, 2015; Tinta, 2015). The leading cause of unemployment is a mismatch between the qualifications of expertise possessed by scholars and market needs (Mada \& Ashar, 2015). A study conducted by Unesco on the suitability of graduates' abilities with the needs of the workforce found that only 52\% answered suitably, the remaining $48 \%$ 
respondent answered unsuitable (Unesco, 2012). The world of work has determined by itself the competencies needed in its world, which may not be suitable for graduates produced by HE. It means that there is a gap between the skills provided by HE graduates and market needs (Harvey, 2000; Teichler, 1999).

This problem has attracted many researchers to trace the competencies needed by the market to make the college alumni get jobs quickly after they graduate (Knight \& Yorke, 2003; Moreland, 2006). Research conducted by Suarta (2017) found the four highest-ranking competencies needed by workers to be able to survive and succeed in the world of work include integrity, intellectual capacity, teamwork skills, analytical, and problem-solving skills. Another study conducted by Menez on MBA graduates who have worked found several competencies relevant to their world of work, including communication, technical expertise, the values of Love of God, honesty, love for truth, and hard work (Meñez, 2014). Discussing the employability of graduates in Asian countries, including Indonesia, Tan conducted the same study. Finally, he formulated some competencies needed by college graduates, so they could easily find work, among others: communication skills, logical, analytical and problem-solving skills, personality, confidence, integrity, flexibility, adaptability, innovation, creativity, and team spirit (Tan \& French-Arnold, 2012).

The results of these studies can be essential findings for HE, to assess the quality of the performance of its graduates, by questioning whether graduates already have the competencies needed in the working world (Støren \& Aamodt, 2010). So to answer this question, it is essential to assess the graduate customer satisfaction of the graduates' performance and competencies in their respective workplaces (Abidin, 2015c; Teichler, 1999).

In the Indonesian context, research on user satisfaction (stakeholders) towards HE performance alumni is still rarely conducted, especially in Islamic Higher Education (IHE). Most of the research took the theme of student satisfaction with educational services in higher education (Ardi Romadhani et al., 2012; Napitupulu et al., 2018) or alumni satisfaction on HE quality (Abidin, 2015a; Rafik \& Priyono, 2018). Some researches also touched several methods to increase the student's satisfaction, like by implementing technology approaches (Jamaluddin et al., 2019), creating experience value (Gunarto \& Hurriyati, 2020) and tracer study services (Soegoto et al., 2018). Meanwhile, research on the user satisfaction of HE alumni itself is still rare to do. This study intends to assess the performance quality of graduates of UIN Maliki Malang Indonesia by measuring the level of graduate customer satisfaction and the competencies of HE graduates. To determine those gaps, the researcher used the Customer Satisfaction Index (CSI) analysis and Importance Performance Analysis (IPA) to see the difference between customer satisfaction and graduates performance. 


\section{Literature Review}

\section{Stakeholders Satisfaction of HE Graduates' Performance}

Satisfaction is a short-term attitude, which results from an evaluation of the experience of consuming goods and services (Athiyaman, 1997). To assess stakeholder's satisfaction is by comparing their perceptions of the performance of a product and its expectations of how the product's performance should be (Abidin, 2015b). The satisfaction of graduate users, as an external customer of HE, can be interpreted as comparing their perceptions of the performance of a college product or graduates and their expectations of how the graduates' performance should be (Abidin, 2015c). This understanding will underlie how to measure graduate user satisfaction by comparing their perceptions and expectations of several competencies possessed by graduates (Guskey, 2007).

Graduates as HE partial products (Cunningham \& Cochi-Ficano, 2002) are the results of the HE production process as a service industry or corporation (Momeni Mahmuee, 2009). HE called an industry because it has a system that processes inputs (human resources, students, infrastructure and finance, etc.) into output in additional student competencies (Peacock \& Ladkin, 2002).

Competence, which is defined as capability, is a set of matters relating to behavior organized for a particular purpose (Peng et al., 2016). The response manifested in goals that are appropriate in various situations and conditions (Ryan et al., 2009). For example, asking and listening to someone is a behavior that is carried out for a specific purpose (Boyatzis, 2008) because of sympathizing with things that happen to that person.

Performance theory is the basic concept of competence (Duysters \& Hagedoorn, 2000), where the maximum performance occurs when one's abilities and talents match the needs and work environment expected (Arifin, 2014). The individual has to perform these abilities and skills (Duysters \& Hagedoorn, 2000). If someone is said to be competent, then this means that the person's performance is following the standards (Barnett, 1994). So that a term called the competency standard appears, which is the qualifications needed by professionals in undergoing their profession or scientific discipline (Trinder, 2008).

The established competency standards can be used to see graduates' performance (Duysters \& Hagedoorn, 2000). Every organization can set this standard, whether government, corporation and even educational institutions, to determine its graduate competences (Bontis et al., 2005; Markides \& Williamson, 1994; Muzenda, 2013). With these competency standards, an assessment of graduate performance can be carried out (Trinder, 2008).

Some assessment standards, such as Indonesian National Accreditation Board (BAN PT), formulating seven competencies that HE graduates must-have, namely: (1) Integrity (ethics and morals), (2) Expertise based on the field of science (professionalism), (3) English skill, (4) ) Mastery of information technology, (5) Communication, (6) Teamwork, and (7) Self-development (Azis \& Wibisono, 2010). Besides, O'Brien 
formulated seven competencies that graduates need to have, including: (1) Communication Skills, (2) Organizational Skills, (3) Leadership, (4) Logic, (5) Effort, (6) Group skills, and (7) Ethics (O’Brien, 2002).

UNESCO (2012) formulated six competencies that must be possessed by college graduates. Those competences are; (1) Communication skills, (2) Logical, analytical and problem-solving skills, (3) Personality, confidence, and integrity, (4) Flexibility and adaptability, (5) Innovation and creativity, and (6) Team spirit (Tan \& French-Arnold, 2012). The various competency assessment standard formulations above can be summarized in the table below.

Table 1

Standards for competency assessment of HE graduates

\begin{tabular}{lll}
\hline BAN PT (2014) & O’Brien (2002) & UNESCO \\
\hline Communication & Communication skill & Communication skills \\
\hline Professionalism & Logic & Logical, analytical and problem solving skills \\
\hline English skill & Leadership & Innovation and creativity \\
\hline Self-development & Effort & Flexibility and adaptability \\
\hline Integrity (ethics and morals) & Ethics & Personality, confidence, and integrity \\
\hline Teamwork & Group skills & Team spirit \\
\hline Use of information technology & Organization skill & \\
\hline
\end{tabular}

There are still many other competency standards used to measure graduates' quality or employability, such as those developed by Suleman ( 2016, 2018), Olojuoulawe (Olojuolawe et al., 2019), and so on. In this study, researchers tend to use the standards developed by Suarta et al. (2017) from their development against the six standards developed by UNESCO.

\section{Problem of Study}

- How high is the level of stakeholder's satisfaction over the quality of performance or competence of Higher Education graduates?

- What dimensions and items of competency of HE graduates should be prioritized and improved in the stakeholder's perspective?

\section{METHOD}

\section{Data Collection and Sample of Study}

This research uses a quantitative approach with a descriptive quantitative type. Data collected using a survey method by taking samples from a population and using a questionnaire as a primary data collection tool (Groves et al., 2011). The population of this research is the users of researched university graduates. The researcher determines the research sample by purposive random sampling. The research subjects are stakeholders who work in institutions that employ graduates of the researched university, such as educational institutions, government agencies, private institutions, etc. Because the number of agencies is vast and spread in various regions, they cannot 
be determined in quantity. Therefore, in this study, researchers only collected data from educational institutions that employ researched university graduates.

According to the university administration data, at the time the research was conducted, the researched university had 15.298 alumni spread throughout Indonesia (UIN Malang, 2018b). Meanwhile, the Tracer Study section shows that around 2891 alumni work in Malang alone, spread across several institutions, especially educational institutions, from elementary schools to tertiary institutions. Due to the wide scope of the alumni's workplace, the researcher limits it to educational institutions where the alumni work. The data obtained by researchers from the Tracer Study Department shows that 44 educational institutions in Malang employ alumni of the researched university (UIN Malang, 2018a). Of the 44 institutions, it is further reduced to 15 educational institutions as research samples, three state universities, three private universities, five higher educational institutions, and four secondary educational institutions. Every institution that we ask to fill out a questionnaire will send 20 questionnaires filled out by the leaders and alumni colleagues at the institution. The number of identified institutions was 15 institutions, and the total number of questionnaires distributed was 300 questionnaires.

The researcher sent the questionnaires to the respondents through manually, post, emails, and WhatsApp. Data collection starts in October 2017 until December 2018. During that time, researchers sent 300 questionnaires, and only 278 respondents returned them. After being selected, the researcher found that only 258 questionaries were eligible for analysis.

\section{Research Instruments}

The study uses an instrument developed by Suarta et al. (2017) with modification. He developed it from several competency standards for employability of higher education graduates previously, such as those developed by Lohman (2004), Husain et al. (2010), Ramli et al. (2010), and UNESCO standards (Asia \& Education, 2012) which were improved again in an international seminar in 2015 (Asia \& Education, 2015). However, after an in-depth study, the research items were focused on using six UNESCO standards with slight adjustments, up to 31 items; communication skill five items, logical, analytical and problem-solving six items, innovation and creativity skill six items, flexibility, and adaptability three items, personality and integrity eight items, and team spirit six items. Respondents asked to indicate their level of satisfaction with the alumni of the researched college worked at their place according to the predetermined criteria and to what extent those criteria are important. They were asked to fill out a questionnaire with a five-point Likert scale ranging from 1 (not satisfactory) to 5 (Very Satisfactory) and 1 (Not important) to 5 (Very Important). 
Tabel 2

Research instrument

Instrument Item Graduates Competencies

1) Convey ideas, opinions, and suggestions to others

2) Hear thoughts, ideas, or advice/suggestions of others

Communication $\frac{2 \text { ) Head and write reports, and other significant letters }}{3 \text { ) Read }}$

Skill 4) Speak foreign languages

5) Use the latest information technology for communication effectiveness

6) Conceptualize an activity

Logical, $\quad$ 7) Apply or carry out an activity

Analytical and 8) Analyze and evaluate a business or job

Problem $\quad 9$ ) Observe or study a problem

Solving Skills 10) Find a way to solve a problem

11) Independence at work

Innovation and 12) Think and give different new ideas

Innovation and 13) Provide a unique touch to the method or tool used in the job

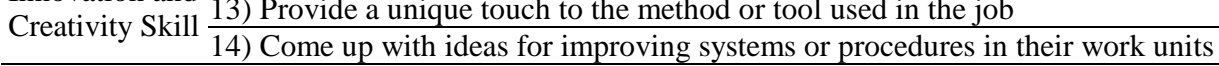

Flexibility and 15) Adapt to various situations and environmental conditions quickly

Adaptability 16 ) Adjust to multiple positions or groups in an organization quickly

17) Socialize with other coworkers

18) Accuracy, and order at work

19) Attitudes of tolerance, friendliness, and respect for others

Confidence, 21) Morality (the ability to distinguish between what is right and what is not)

and Integrity 22) Transparency and honesty

23) The attitude of responsibility at work

24) Confidence

25) Caring for others

26) Commitment to regulations and organizational success

27) Understand and play an essential role in the organization with full responsibility

Team Spirit 28) Avoid superiority and want to win alone

29) Have open discussions, and respect the opinions of others

30) Be fair to other colleagues

31) Willingness to cooperate with other partners

The items in the instrument above will be measured using a 5 point Likert scale. By asking the level of satisfaction (perception) and level of importance (expectations) for the quality of HE graduates' performance with grades 1 to 5 , start from not satisfactory to very satisfactory for asking satisfaction level and from not important to very important for asking importance level.

\section{Data analysis}

Data analysis is intended to simplify data in a form that is easier to read and interpret. Following the formulation of the problem presented, the data analysis methods used in this study are percentage analysis, Customer Satisfaction Index (CSI) and Importance 
Performance Analysis (IPA). Customer Satisfaction Index (CSI) is quantitative analysis in the form of a percentage of users that shows the level of management quality (Eklof \& Westlund, 1998) and is first developed by Martilla \& James (1977). In this research, CSI used to analyze the graduate user satisfaction on the quality of performance/competence of HE graduates, considering the level of importance of the performance items or competencies for graduate users. This CSI calculation will use the CSI (Customer Satisfaction Index) formula, adapted from Bhote (1996) by the following steps:

(1) Calculating the value of importance (I). After each item of performance/competence of graduates is given a grade or weight rating according to the score above, the first step is to look for the total sum of the importance level (I)

(2) Calculate the Weight of Satisfaction Level (P). In contrast to the weight of the level of importance sought for the total score, for the weight of satisfaction, what is sought is the average per dimension of the competency/item of competence, not the total number.

(3) Calculate the Customer Satisfaction Index (CSI). After each whole average importance level (I) and the average level of performance perception (P) known, then the next is to multiply between the total score I and the average P so that the overall rating obtained.

Based on the above calculation, the maximum value of CSI is $100 \%$. A CSI score of $50 \%$ or lower indicates a low level of satisfaction or a poor or even needy quality of graduates' competency, following in detail the categories of Customer satisfaction of users of graduates and the level of quality of graduate competencies based on the CSI scores obtained.

Tabel 3

IPA values

\begin{tabular}{lll}
\hline IPA Values & Satisfaction Category & Service Quality Category \\
\hline $81 \%-100 \%$ & Very satisfied & Very good \\
\hline $66 \%-80,99 \%$ & Satisfied & Good \\
\hline $51 \%-65,99 \%$ & Quite satisfied & Pretty good \\
\hline $35 \%-50,99 \%$ & Less satisfied & Less good \\
\hline $0 \%-34,99 \%$ & Not satisfied & Not good \\
\hline
\end{tabular}

Quadrant Importance Performance Analysis (IPA)

The IPA analysis used in this study refers to IPA's use by Sasson \& Douglas (2006) by modifying the research objectives. The steps of analysis in this area are as follows:

(1) Calculate the Mean Expectations and perceptions of each respondent.

(2) Plotting Cartesian Expectations of Mean Expectations and Perceptions into the IPA Quadrant, as shown in Figure 1. The center-line axis (average) must be found or the Xaxis and Center-line for the y-axis. 


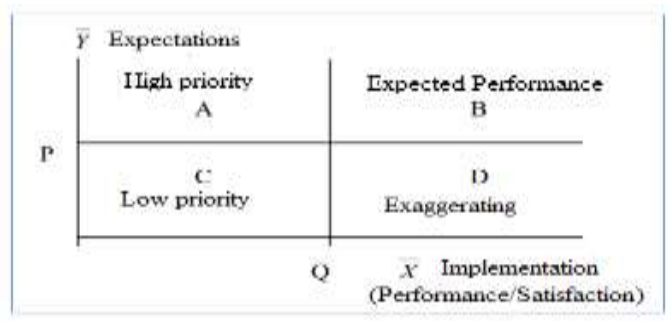

Figure 1

Cartesian diagram

Performing interpretations and analysis around the dimensions and items of competencies that fall into categories I, II, III, and IV:

1. Quadrant I: High Priority. Sizes or items of performance/competencies located in this quadrant are dimensions/items of performance that are important for graduate users.

2. Quadrant II: Maintain Performance. Dimensions/items located in this quadrant are dimensions/items of performance/competence of graduates that are considered essential and have met customers' expectations.

3. Quadrant IIII: Low Priority. Dimensions/items of performance/competence of graduates located in this quadrant have a level of perception or performance that is not too satisfying for Customers and is also considered not too necessary or too expected for its existence by Customers.

4. Quadrant IV: Exagragating. The instrument's dimensions/items located in this quadrant have the lowest degree beyond the level of interest expected by Customers or users.

\section{FINDINGS}

\section{Profile of Respondents}

The research questionnaire was filled in by the users of the graduates who were managers, teachers, supervisors or coworkers of the graduates. In the survey, several question items describe the gender and occupation of the respondent that reflects their identity.

Table 4

Distribution of demographic identity of respondent

\begin{tabular}{lllll}
\hline Cluster & Identity & $\mathrm{F}$ & $\mathrm{N}$ & Percentage \\
\hline \multirow{3}{*}{ Institution } & Higher Education & 6 & 102 & $39.5 \%$ \\
& Senior high school & 5 & 84 & $32.5 \%$ \\
& Junior high school & 4 & 72 & $28 \%$ \\
\hline \multirow{2}{*}{ Sex } & Woman & & 119 & $46 \%$ \\
& Man & & 139 & $54 \%$ \\
\hline \multirow{5}{*}{ Occupation } & Manager & & 45 & $17.5 \%$ \\
& Teacher/lecturer & 129 & $50 \%$ \\
& Educational staff & 49 & $19 \%$ \\
& Supervisor & 35 & $13.6 \%$ \\
\hline
\end{tabular}

\section{Instrument Realibility and Validity}

Before being used as a measurement, the research instrument was tested for validity and reliability with the Cronbach Alpha coefficient. Based on the Cronbach Alpha analysis, the following results obtained: 
Tabel 5

Reliability scores

\begin{tabular}{lll}
\hline Construct & Number of items & Cronbach's $\alpha$ \\
\hline 1. Communication skill & 5 & 0.923 \\
\hline 2. Logical, analytical and problem solving skills & 6 & 0.934 \\
\hline 3. Innovation and creativity skill & 3 & 0.876 \\
\hline 4. Flexibility and adaptability & 3 & 0.846 \\
\hline 5. Personality, confidence, and integrity & 8 & 0.943 \\
\hline 6. $\quad$ Team spirit & 6 & 0.831 \\
\hline
\end{tabular}

Table 5 shows the results of the data validity test with Cronbach Alpha ranging from $0.831-0.943$, exceeding the recommended minimum level of 0.7 , as recommended by Nunnally (1978). It is feasible to be used as a measuring tool.

Meanwhile, to test the items' validity, the researcher used the Pearson product-moment correlation with SPSS. Before being distributed to respondents, the research instrument was tested on 20 people outside the research institution. The test results showed that all the questions results between $0.542-0.834$ above 0.444 , so they were declared valid because the $r$ table's value for 20 respondents is 0.444 , so if the $r$ count per item is greater than it is declared valid.

\section{Analysis of Customer Satisfaction Index}

Based on the data analysis results, the Customer Satisfaction Index (CSI) calculations on HE graduates' performance or competencies for each skill illustrated in table 6 . The table shows that the total CSI value of graduates' competencies is $67.50 \%$, which means that, in general, costumers are satisfied with the university graduates' performance or skills. It shows that the quality of performance of graduates of the researched university has been rated 'good' by customers.

Table 6

Results of the customer satisfaction index analysis of graduates' performance

\begin{tabular}{lllllllc}
\hline Competences & $\begin{array}{l}\text { Mean of } \\
\text { Importance }\end{array}$ & $\begin{array}{l}\text { Mean of } \\
\text { Satis- } \\
\text { faction (S) }\end{array}$ & $\begin{array}{l}\text { Scor (S) } \\
\text { (I x P) }\end{array}$ & $\begin{array}{l}\text { CSI }= \\
\text { S/(5xI) }\end{array}$ & $\begin{array}{l}\text { Satisfaction } \\
\text { Category }\end{array}$ & $\begin{array}{l}\text { Compe- } \\
\text { tency } \\
\text { category }\end{array}$ & Rank \\
\hline Communi-cation skill & 4.59 & 3.69 & 16.92 & $73.76 \%$ & satisfied & good & 1 \\
\hline $\begin{array}{l}\text { Logical. analytical and } \\
\text { problem solving skills }\end{array}$ & 4.56 & 3.00 & 13.71 & $60.07 \%$ & $\begin{array}{l}\text { quite } \\
\text { satisfied }\end{array}$ & $\begin{array}{l}\text { quite } \\
\text { good }\end{array}$ & 6 \\
\hline $\begin{array}{l}\text { Innovation and } \\
\text { creativity skill }\end{array}$ & 4.84 & 3.25 & 15.75 & $65.07 \%$ & $\begin{array}{l}\text { quite } \\
\text { satisfied }\end{array}$ & $\begin{array}{l}\text { quite } \\
\text { good }\end{array}$ & 4 \\
\hline $\begin{array}{l}\text { Flexibility and } \\
\text { adaptability }\end{array}$ & 4.23 & 3.65 & 15.41 & $72.93 \%$ & satisfied & good & 2 \\
\hline $\begin{array}{l}\text { Personality. confidence. } \\
\text { and integrity }\end{array}$ & 4.29 & 3.11 & 13.33 & $62.20 \%$ & $\begin{array}{l}\text { quite } \\
\text { satisfied }\end{array}$ & $\begin{array}{l}\text { quite } \\
\text { good }\end{array}$ & 5 \\
\hline Team spirit & 4.60 & 3.55 & 16.34 & $71.00 \%$ & satisfied & good & 3 \\
\hline & CSI Total Mean & & $67.50 \%$ & & good & \\
\hline
\end{tabular}

Based on graduates' competency rating, the three highest ranks included in the performance or competency category have been good. They have provided stakeholder satisfaction for graduates are communication skills, flexibility, adaptability, and team spirit, with the respective CSI values in the sequence $73.76 \% ; 72.93 \%$ and $72.93 \%$. While the three lowest in the category of performance or competency level and only 
giving 'quite' satisfaction to graduate users are innovation and creativity skills, personality, confidence, integrity, logical, analytical and problem-solving skills, with their respective values sequentially is $65.07 \% ; 62.20 \%$; $60.07 \%$.

Tabel 7

Customer satisfaction index (CSI) of graduate competences

\begin{tabular}{|c|c|c|c|c|c|c|c|}
\hline $\begin{array}{l}\text { No } \\
\text { Atribut }\end{array}$ & $\begin{array}{l}\text { Mean of } \\
\text { Importance }\end{array}$ & $\begin{array}{l}\text { Mean of } \\
\text { Satisfaction (S) }\end{array}$ & $\begin{array}{l}\text { Scor }(S)= \\
(I \times P)\end{array}$ & $\begin{array}{l}\mathrm{CSI}= \\
\mathrm{S} /(5 \mathrm{xI})\end{array}$ & $\begin{array}{l}\text { Satisfaction } \\
\text { Category }\end{array}$ & $\begin{array}{l}\text { Quality competency } \\
\text { category }\end{array}$ & Rank \\
\hline 31 & 4.7 & 4.04 & 18.99 & $80.80 \%$ & satisfied & good & 1 \\
\hline 17 & 4.2 & 3.9 & 16.38 & $78.00 \%$ & satisfied & good & 2 \\
\hline 16 & 4.26 & 3.84 & 16.36 & $76.80 \%$ & satisfied & good & 3 \\
\hline 30 & 4.6 & 3.82 & 17.57 & $76.40 \%$ & satisfied & good & 4 \\
\hline 2 & 4.52 & 3.82 & 17.27 & $76.40 \%$ & satisfied & good & 5 \\
\hline 5 & 4.64 & 3.7 & 17.17 & $74.00 \%$ & satisfied & good & 6 \\
\hline 1 & 4.74 & 3.68 & 17.44 & $73.60 \%$ & satisfied & good & 7 \\
\hline 4 & 4.5 & 3.64 & 16.38 & $72.80 \%$ & satisfied & good & 8 \\
\hline 21 & 4.34 & 3.62 & 15.71 & $72.40 \%$ & satisfied & good & 9 \\
\hline 3 & 4.54 & 3.6 & 16.34 & $72.00 \%$ & satisfied & good & 10 \\
\hline 26 & 4.62 & 3.6 & 16.63 & $72.00 \%$ & satisfied & good & 11 \\
\hline 29 & 4.72 & 3.48 & 16.43 & $69.60 \%$ & satisfied & good & 12 \\
\hline 27 & 4.6 & 3.48 & 16.01 & $69.60 \%$ & satisfied & good & 13 \\
\hline 22 & 4.36 & 3.38 & 14.74 & $67.60 \%$ & satisfied & good & 14 \\
\hline 13 & 4.9 & 3.32 & 16.27 & $66.40 \%$ & satisfied & good & 15 \\
\hline 12 & 4.78 & 3.26 & 15.58 & $65.20 \%$ & quite satisfied & pretty good & 16 \\
\hline 11 & 4.46 & 3.22 & 14.36 & $64.40 \%$ & quite satisfied & pretty good & 17 \\
\hline 15 & 4.22 & 3.2 & 13.50 & $64.00 \%$ & quite satisfied & pretty good & 18 \\
\hline 23 & 4.28 & 3.2 & 13.70 & $64.00 \%$ & quite satisfied & pretty good & 19 \\
\hline 24 & 4.58 & 3.2 & 14.66 & $64.00 \%$ & quite satisfied & pretty good & 20 \\
\hline 25 & 4.06 & 3.2 & 12.99 & $64.00 \%$ & quite satisfied & pretty good & 21 \\
\hline 14 & 4.84 & 3.18 & 15.39 & $63.60 \%$ & quite satisfied & pretty good & 22 \\
\hline 7 & 4.6 & 3.16 & 14.54 & $63.20 \%$ & quite satisfied & pretty good & 23 \\
\hline 6 & 4.54 & 3.08 & 13.98 & $61.60 \%$ & quite satisfied & pretty good & 24 \\
\hline 10 & 4.64 & 3.06 & 14.20 & $61.20 \%$ & quite satisfied & pretty good & 25 \\
\hline 19 & 4.22 & 2.96 & 12.49 & $59.20 \%$ & quite satisfied & pretty good & 26 \\
\hline 28 & 4.38 & 2.88 & 12.61 & $57.60 \%$ & quite satisfied & pretty good & 27 \\
\hline 20 & 4.18 & 2.84 & 11.87 & $56.80 \%$ & quite satisfied & pretty good & 28 \\
\hline 8 & 4.54 & 2.76 & 12.53 & $55.20 \%$ & quite satisfied & pretty good & 29 \\
\hline 9 & 4.6 & 2.74 & 12.60 & $54.80 \%$ & quite satisfied & pretty good & 30 \\
\hline 18 & 4.26 & 2.48 & 10.56 & $49.60 \%$ & less satisfied & less good & 31 \\
\hline
\end{tabular}

Table 7 shows the CSI calculation results for each of the performance competencies possessed by HE researched graduates. It shows that 15 items of skill have a CSI value category 'satisfied,' and 15 items have a CSI value category 'quite satisfied.' It means that the quality of performance or competencies felt by customers who use graduates on these competencies is sufficient and needs to be improved to be even better. The fifteen items are the $6^{\text {th }}, 7^{\text {th }}, 8^{\text {th }}, 9^{\text {th }}, 10^{\text {th }}, 11^{\text {th }}, 12^{\text {th }}, 14^{\text {th }}, 15^{\text {th }}, 19^{\text {th }}, 20^{\text {th }}, 23^{\text {th }}, 24^{\text {th }}, 25^{\text {th }}$, and $28^{\text {th }}$. Less good category revealed in the $18^{\text {th }}$ competence while users of graduates felt good for the remaining competency attributes.

\section{Quadrant Index Performance Analysis (QIPA)}

The Index Performance Analysis (IPA) employed in this research aims to map the quality level of graduates 'competencies and graduate users' expectations towards them in the quadrant, as reflected in Figure 1, which is explained earlier. This quadrant 
illustrates the average value between the level of interest (expectations) of Customers and their level of satisfaction (perception) of graduates' performance or competence in a vertical and horizontal line. The vertical line represents whether or not a competency is essential according to the user's perception of graduates. The horizontal line shows the user's perception of the skills of researched university graduates. The more upward the graph means, the more critical, and the more right the chart means, the more satisfying according to customer perception.

First, the researcher maps the competency items of graduates who fall into the quadrant's four categories. It is necessary to determine the average value of each competency attribute, both the level of importance and satisfaction of all respondents, to find the center-line as reflected in table 8 .

Table 8

The average value of importance and satisfaction level

\begin{tabular}{|c|c|c|c|c|}
\hline No Atribut & $\begin{array}{l}\text { Mean of } \\
\text { Satisfaction }\end{array}$ & $\begin{array}{l}\text { Mean of } \\
\text { importance }\end{array}$ & Gap S-I & Ranking \\
\hline 1 & 3.68 & 4.74 & -1.06 & 18 \\
\hline 2 & 3.82 & 4.52 & -0.7 & 28 \\
\hline 3 & 3.6 & 4.54 & -0.94 & 22 \\
\hline 4 & 3.64 & 4.5 & -0.86 & 24 \\
\hline 5 & 3.7 & 4.64 & -0.94 & 23 \\
\hline 6 & 3.08 & 4.54 & -1.46 & 9 \\
\hline 7 & 3.16 & 4.6 & -1.44 & 10 \\
\hline 8 & 2.76 & 4.54 & -1.78 & 2 \\
\hline 9 & 2.74 & 4.6 & -1.86 & 1 \\
\hline 10 & 3.06 & 4.64 & -1.58 & 6 \\
\hline 11 & 3.22 & 4.46 & -1.24 & 14 \\
\hline 12 & 3.26 & 4.78 & -1.52 & 7 \\
\hline 13 & 3.32 & 4.9 & -1.58 & 5 \\
\hline 14 & 3.18 & 4.84 & -1.66 & 4 \\
\hline 15 & 3.2 & 4.22 & -1.02 & 20 \\
\hline 16 & 3.84 & 4.26 & -0.42 & 30 \\
\hline 17 & 3.9 & 4.2 & -0.3 & 31 \\
\hline 18 & 2.48 & 4.26 & -1.78 & 3 \\
\hline 19 & 2.96 & 4.22 & -1.26 & 13 \\
\hline 20 & 2.84 & 4.18 & -1.34 & 12 \\
\hline 21 & 3.62 & 4.34 & -0.72 & 27 \\
\hline 22 & 3.38 & 4.36 & -0.98 & 21 \\
\hline 23 & 3.2 & 4.28 & -1.08 & 17 \\
\hline 24 & 3.2 & 4.58 & -1.38 & 11 \\
\hline 25 & 3.2 & 4.06 & -0.86 & 25 \\
\hline 26 & 3.6 & 4.62 & -1.02 & 19 \\
\hline 27 & 3.48 & 4.6 & -1.12 & 16 \\
\hline 28 & 2.88 & 4.38 & -1.5 & 8 \\
\hline 29 & 3.48 & 4.72 & -1.24 & 15 \\
\hline 30 & 3.82 & 4.6 & -0.78 & 26 \\
\hline 31 & 4.04 & 4.7 & -0.66 & 29 \\
\hline total & 103.34 & 139.42 & -36.08 & \\
\hline c-line & 3.33 & 4.50 & -1.16 & \\
\hline
\end{tabular}


Table 8 illustrates that the C-Line of importance is 4.50, and the C-Line of satisfaction is 3.33. The average gap that occurs is equal to -1.16 . The data shows a gap between stakeholder assessment of graduate competence and stakeholder expectations or level of importance of 1.16, which means that customer expectations are greater than the reality of graduate competencies. This gap occurs because the quality of the product obtained by customers does not match their expectations, so the producer must improve the product's quality to meet customer expectations. In the context of researched tertiary institutions, it must increase customer satisfaction by improving the quality of its education output by 1.16 , especially on competency points that customers consider insufficient.

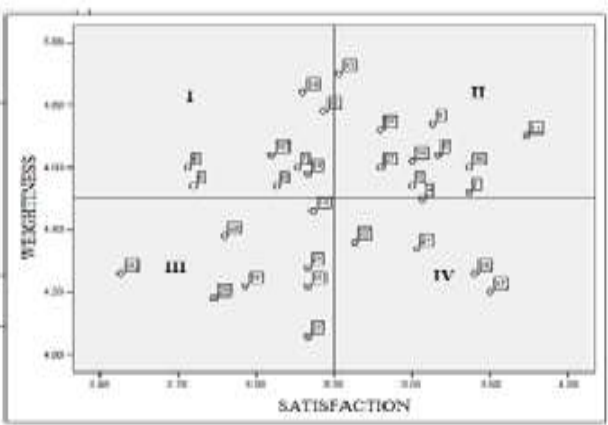

Figure 2

Cartesian diagram of graduates competency items

Data processing by IPA analysis in the form of a Cartesian diagram results in a mapping of graduates' competency attributes that are included in quadrants I, II, III, and IV.

Table 9 illustrates that eight service items fall into the main priority category, eleven service items in the retained category, eight items in the low priority category, and six items in the excessive priority category.

Table 9

The competency attributes of graduates in quadrants I, II, III and IV

\begin{tabular}{llll}
\hline Quadrant & \multicolumn{1}{c}{ Category } & \multicolumn{1}{c}{ Number of service items } & Total \\
\hline I & Main priority & $6,7,8,9,10,12,14,24$ & 8 items \\
\hline II & Be maintained & $1,2,3,4,13,26,27,29,5,30,31$ & 11 items \\
\hline III & Low Priority & $11,15,18,19,20,28,23,25$ & 8 items \\
\hline IV & Exaggerated & $16,17,21,22$. & 4 items \\
\hline
\end{tabular}

IPA analysis carried out on each dimension of graduate competencies, which consists of: (1) communication skills, (2) logical, analytical and problem-solving skills, (3) innovation and creativity skills, (4) flexibility and adaptability, (5) Personality, confidence, and integrity, and (6) team spirit. In mapping the attributes in the quadrant, firstly, the researcher searches the average value of the user's perception on the importance level and the satisfaction level in each dimension and determining the C-line for the vertical and horizontal axes. 
Table 10

The average value of the level of importance, level of satisfaction, and C-line

\begin{tabular}{|c|c|c|c|c|c|}
\hline No & Comptences & $\begin{array}{l}\text { Mean of } \\
\text { Satisfaction (S) }\end{array}$ & $\begin{array}{l}\text { Mean of } \\
\text { Importance (I) }\end{array}$ & Gap S-I & Rank \\
\hline 1 & Communication skill & 3.69 & 4.59 & -0.90 & 5 \\
\hline 2 & $\begin{array}{l}\text { Logical, analytical and problem } \\
\text { solving skills }\end{array}$ & 3.00 & 4.56 & -1.56 & 2 \\
\hline 3 & Innovation and creativity skill & 3.25 & 4.84 & -1.59 & 1 \\
\hline 4 & Flexibility and adaptability & 3.65 & 4.23 & -0.58 & 6 \\
\hline 5 & $\begin{array}{l}\text { Personality, confidence, and } \\
\text { integrity }\end{array}$ & 3.11 & 4.29 & -1.18 & 3 \\
\hline 6 & Team spirit & 3.55 & 4.60 & -1.05 & 4 \\
\hline \multicolumn{2}{|c|}{ Total } & 20.25 & 27.11 & -6.86 & \\
\hline \multicolumn{2}{|c|}{ C - Line } & 3.38 & 4.52 & & \\
\hline
\end{tabular}

Table 9 shows that the $\mathrm{C}$-line for the level of graduate user satisfaction (horizontal axis) is 3.38, while the $\mathrm{C}$-line for the level of importance (vertical axis) is 4.52. The total gap between the value of expectations and customer satisfaction is 6.86 , which means that customer expectations higher than their satisfaction in using the product. The researched university should improve its alumni quality to point out that the gap between expectations and customer satisfaction can be eliminated.

While the results of the IPA analysis using a Cartesian diagram for each competency shown in Figure 3.

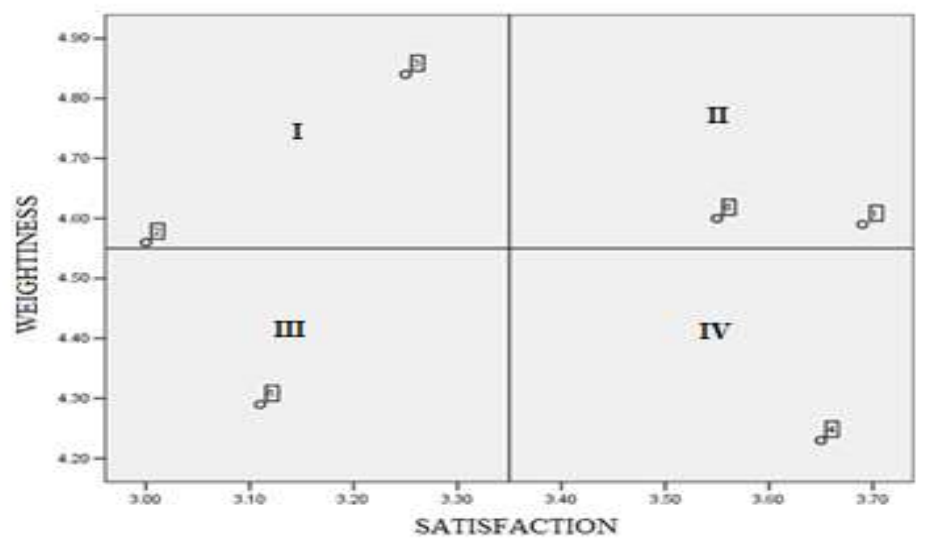

Figure 3

Cartesian diagram of graduates competency items

Based on the picture, the competency mapping into quadrants I, II, III, and IV, can be seen in table 11.

Table 11 shows that (2) logical, analytical, and problem-solving skills, and (3) Innovation and creativity skills are the main priority categories (quadrant I), which the university must consider. These competencies are in the low level of customer satisfaction, even though the level of importance in work is quite high. 
Table 11

Mapping competency dimensions of graduates in quadrants I, II, III and IV

\begin{tabular}{lll}
\hline Quadrant & Category & Dimention of services \\
\hline I & High priority & $\begin{array}{l}\text { (2) Logical, analytical and problem solving skills; (3) } \\
\text { Innovation and creativity skill }\end{array}$ \\
\hline II & Expected/maintain & (1) communication skill; dan (6) team spirit \\
\hline III & Low Priority & (5)Personality, confidence, and integrity \\
\hline IV & Exaggerated & (4) Flexibility and adaptability \\
\hline
\end{tabular}

Furthermore, the dimensions included in the level of comfort with graduate competencies are following expectations or the standard of importance in the world of work. The quality of performance must be maintained and included in quadrant II are (1) communication skills, and (6) teams spirit. Competencies included in the low priority category (quadrant III) are (5) Personality, confidence, and integrity. In contrast, skills included in the excessive category (quadrant IV) are (4) Flexibility and adaptability.

\section{DISCUSSION}

\section{Customer satisfaction level of graduates performance}

Table 6 shows that the Customer Satisfaction Index (CSI) of graduate performance was in the satisfied category or, in other words, was in good quality. However, there are still three dimensions of competency, according to Customers in the 'quite satisfied' category, namely, first, innovation and creativity skills; second, personality, confidence, and integrity; and third, logical, analytical, and problem-solving skills.

Table 7 shows that all items from logical, analytical, and problem-solving skills competencies got a 'good' score of the three competencies. While from the competence of innovation and creativity skills, two competency items are in the category of 'quite good,' namely item 12 (ability to think and give different new ideas), and 14 (ability to come up with ideas for improving systems or procedures in work unit). From the flexibility and adaptability competencies, two attributes are in the category of 'good,' namely 15 (the ability to adapt to various situations and environmental conditions quickly) and 19 (attitude of tolerance, friendliness, and respect for others).

Besides the attributes of personality competence, confidence, and integrity, one competency item is in the category of 'not good.' Namely item number 18 (accuracy and order in work), and four competency items that are in the type of 'pretty good,' namely item number 20 (emotional stability/maturity); item number 23 (attitude of responsibility at work); item number 24 (self-confidence), and item number 25 (concern for others). From team spirit competence, only one item gets the category of 'good enough' is the item number 28, (ability to avoid superiority and want to win alone).

Table 10 shows the gap between the mean of satisfaction and the mean of importance ranges from $0.58-1.59$, with the C-Line averaging 1.52 . Thus, the competency items in the gap $\geq 1.52$ must be a concern in the future learning process are logical, analytical, and problem-solving competencies with the gap score 1.56, and innovation and creativity competencies with the gap score 1.59. 
This study supports several previous studies on user satisfaction of higher education alumni in Indonesia. The results of the Kisworo et al. (2018) survey showed that the institutions and companies that became respondents, $67 \%$ of respondents said they were satisfied with the PLS alumni in working. In comparison, the category was very satisfied as many as $19 \%$. Respondents considered less satisfied reaches 14\%. Meanwhile, Setyaningsih's research (Setyaningsih \& Abrori, 2013) showed that the users of higher education graduates were researched and were not satisfied with their alumni's performance because there was a gap between expectations and alumni performance of 0.82. Likewise, Sulvinajayanti's research on the quality of graduates in Pare-pare from the customer's perspective showed, which only gave a satisfactory assessment for graduates of IAIN Pare-pare (Jayanti et al., 2019). This study also confirms the existence of a gap between the expectations of higher education graduates users and the quality of college alumni in their view. It indicates that universities in Indonesia, especially research universities, are always required to improve their quality of products to meet customer expectations and satisfy them.

\section{Priority Competencies of Graduates that must take note in the Teaching Quality}

The analysis of data using Cartesian diagrams or Natural Sciences Analysis, as shown in Figure 3 and Table 11, indicates that there are two dimensions of graduate competencies that the university must prioritize (in quadrant I) to improve teaching in the coming years. The two competencies are logical, analytical, and problem-solving skills; and Innovation and creativity skills. Both dimensions are considered very important by customers, but they consider it less on alumni competency, with the gap reaches 1.561.59 .

Various studies have shown the importance of these two competencies in the world of work. In the Indonesian context today, both dimensions considered the main competencies to enter the world of work (Suarta et al., 2018) and are most needed in the 21st century (Afandi et al., 2019; Wrahatnolo, 2018). Benedict (2008) also revealed that logical, analytical, and problem-solving skills became the second most crucial competency, while innovation and creativity skills became the seventh most crucial competency for employees in the 21 st century. Logical, analytical, and problem-solving skills are among the four highest-ranked competency attributes needed by workers to survive and succeed in the world of work (Suarta et al., 2017).

The administrators of educational institutions must realize this condition. Providing learning based on thinking ability is essential for several reasons, including: first, this ability is needed in the face of rapid environmental and technological change. Second, in general, students lack the development of good thinking skills. Third, although many people believe that we are born with the ability to think critically and creatively, research has proven that this ability can be taught and learned (Cotton, 2000).

Synder \& Synder (2008) emphasized that critical thinking is taught to students in three ways in teaching activities. First, use learning strategies that make students active in the learning process, rather than on teacher-centered learning. Second, focus more on the learning process rather than on the content or material. Third, use assessment techniques that make students get an intellectual challenge to think rather than just testing memory 
(memorization). Barriers that can frustrate critical thinking based learning are the lack of training for teachers, limited resources, and limited time (Davies, 2015). So that the purpose of this thought-based activity can run well, the instructor can encourage students to learn actively by using effective questioning techniques, which can help students to think critically. These techniques were explained by Cotton, among others, by repeating orders, giving reinforcement, giving opportunities to ask more questions during discussions, and extending the time of question and answer (Garrett et al., 1996).

Furthermore, other competencies that need to consider, even if only a low priority (which is in quadrant III), are the personality, confidence, and integrity competencies. This competency in the previous CSI analysis also only got the 'quite good' category, with a gap range of -1.18 (Table 11). In several studies on graduate quality and employability skills, personality was also not included exactly in one of the dimensions considered important in the field of work (Ahsan et al., 2013; Braun \& Brachem, 2015; Humburg \& Van der Velden, 2015; Teijeiro et al., 2013). Suleman (2018) conducting a meta-analysis of several journals about employability skills, he does not directly incorporate personality into its dimensions. But self-confidence and self-management are included in one of the criteria for employability skills. Meanwhile, Velasco (2012), Cheong et al. (2016), and Kavanagh \& Drennan (2008) include personality as an important criterion in the world of work in the $21^{\text {th }}$ century.

Based on the results of the quadrant analysis in Figure 3, the competencies included in quadrant II are communication skills and team spirit. Both competencies based on Customer perception have provided satisfaction following their expectations while the competencies included in quadrant IV (excessive-quality) are Flexibility and adaptability.

The three competencies in quadrants II and IV are competencies that are considered good quality. This finding is supported by the results of CSI calculations, which put these three graduates competencies in the 'good' category, which means that they have given satisfaction to graduate users' customers. It can be understood because the university's learning system is based on seminars and discussions, as well as based on research, which is often conducted in groups (Pollock et al., 2011). Conferences and workshops can practice students' ability to convey and hear others' opinions, while research can train students to adapt and be flexible in all situations. Research activities carried out in groups can improve the ability to work together between one student and other students (Jagosh et al., 2012). This trains each individual to respect, be fair and honest with one another. Thus this type of learning can continue to be carried out by providing improvements to the learning methods related to how the lecturer teaches so that the deficiencies in quadrants I and III can be corrected. Based on Table 10 of the mapping results, there are still eight items in quadrant I and eight items in quadrant II that the university needs to consider in printing student competent according to the workforce's needs.

\section{CONCLUSION}

The level of customer satisfaction on the quality of graduates of researched university falls within the range of 'satisfied' categories, which means that overall the quality of 
graduates' performance or skill has been rated 'good' by Customer. However, there are still three competencies that are considered 'sufficient' by Customers-first, innovation and creativity skills. Second, personality, confidence, and integrity; and third, logical, analytical, and problem-solving skills.

Base on research analysis, the graduates competency that researched university need to consider to improve in the quality of teaching for future are the competencies of logical, analytical \& problem-solving skills, innovation, creativity, personality, confidence, and integrity. These items are competencies that get low ratings from customers but are considered important by them, resulting in a high gap between customer satisfaction and alumni quality.

\section{Recommendation, Limitation, and Suggestion for Further Research}

The researched university needs to increase the level of satisfaction of their graduate users because they judge that their graduates' quality is at the good and quite good levels. The researched universities must work harder to improve their graduates' quality, especially on aspects that are considered insufficient by them, to fulfill their expectations, and to make them satisfied with the performance of graduates.

It is recommended that researched university focus more on developing competencies of logical, analytical \& problem-solving skills, innovation, creativity, personality, confidence, and integrity. These competencies are considered insufficient because there is still a large gap between alumni satisfaction and quality.

Higher education institutions should always conduct periodic evaluations of the quality of alumni and customer satisfaction with their performance to know which elements need to be improved periodically.

This study is limited in researching stakeholder's satisfaction with one university's alumni only. However, the models and instruments applied could serve as a basis for measuring and evaluating higher education quality more generally from stakeholder's perspectives. The next research is expected to sample more universities in Indonesia to make the research results generalized to the Indonesian context.

Meta-analysis on Researching the Customers satisfaction on Higher education performance and It's alumni qualificaion need to be conducted, to know deeply the method, approaches, mesuares, analysis used, and the results achieved. From there, further research can determine the direction more precisely.

\section{REFERENCES}

Abidin, M. (2015a). Alumni satisfaction on curriculum structure and learning process in Indonesian Islamic University. International Journal of Scientific Research and Education, 3(2), 2900-2905.

Abidin, M. (2015b). Students' Perception of Service Quality Dimensions in Islamic Higher Education. 4(1), 6.

Abidin, M. (2015c). Higher Education Quality: Perception Differences among Internal and External Stakeholders. International Education Studies, 8(12), 185. https://doi.org/10.5539/ies.v8n12p185 
Afandi, A., Sajidan, S., Akhyar, M., \& Suryani, N. (2019). Development Frameworks of the Indonesian Partnership 21st-Century Skills Standards for Prospective Science Teachers: A Delphi Study. Jurnal Pendidikan IPA Indonesia, 8(1), 89-100.

Ahsan, K., Ho, M., \& Khan, S. (2013). Recruiting project managers: A comparative analysis of competencies and recruitment signals from job advertisements. Project Management Journal, 44(5), 36-54.

Ansell, B. W. (2008). University challenges: Explaining institutional change in higher education. World Politics, 60(2), 189-230. https://doi.org/DOI: https://doi.org/10.1353/wp.0.0009

Ardi Romadhani, Hidayatno Akhmad, \& Yuri M. Zagloel Teuku. (2012). Investigating relationships among quality dimensions in higher education. Quality Assurance in Education, 20(4), 408-428. https://doi.org/10.1108/09684881211264028

Arifin, H. M. (2014). The Influence of Competence, Motivation, and Organisational Culture to High School Teacher Job Satisfaction and Performance. International Education Studies, 8(1), p38. https://doi.org/10.5539/ies.v8n1p38

Athiyaman, A. (1997). Linking student satisfaction and service quality perceptions: The case of university education. European Journal of Marketing.

Barnett, R. (1994). The limits of competence: Knowledge, higher education and society. ERIC.

Benedict, A. (2008). Critical Skills Needs and Resourses for the Changing Workforce. The Wall Street Career Journal.

Bhote, K. R. (1996). Beyond customer satisfaction to customer loyalty: The key to geater profitability. AMA.

Bontis, N., Wu, S., Chen, M.-C., Cheng, S.-J., \& Hwang, Y. (2005). An empirical investigation of the relationship between intellectual capital and firms' market value and financial performance. Journal of Intellectual Capital. https://doi.org/DOI $10.1108 / 14691930510592771$

Boyatzis, R. E. (2008). Competencies in the 21 Century [Journal of Management Development]. Pdfslide.Net. https://pdfslide.net/documents/boyatzis-competencies-inthe-21-century.html

Braun, E. M., \& Brachem, J.-C. (2015). Requirements higher education graduates meet on the labor market. Peabody Journal of Education, 90(4), 574-595.

Cheong, K.-C., Hill, C., Fernandez-Chung, R., \& Leong, Y.-C. (2016). Employing the 'unemployable': Employer perceptions of Malaysian graduates. Studies in Higher Education, 41(12), 2253-2270.

Cotton, K. (2000). The schooling practices that matter most.

Cunningham, B. M., \& Cochi-Ficano, C. K. (2002). The determinants of donative revenue flows from alumni of higher education: An empirical inquiry. Journal of Human Resources, 540-569. https://www.jstor.org/stable/3069681?seq=1 
Davies, M. (2015). A model of critical thinking in higher education. In Higher education: Handbook of theory and research (pp. 41-92). Springer. https://doi.org/10.1007/978-3-319-12835-1_2

Duysters, G., \& Hagedoorn, J. (2000). Core competences and company performance in the world-wide computer industry. The Journal of High Technology Management Research, 11(1), 75-91. https://doi.org/10.1016/S1047-8310(00)00022-5

Eklof, J. A., \& Westlund, A. (1998). Customer satisfaction index and its role in quality management. Total Quality Management, 9(4-5), 80-85. https://doi.org/10.1080/0954412988613

Garrett, M., Schoener, L., \& Hood, L. (1996). Debate: A teaching strategy to improve verbal communication and critical-thinking skills. Nurse Educator, 21(4), 37-40. https://journals.lww.com/nurseeducatoronline/Abstract/1996/07000/Debate_A_Teachi ng_Strategy_to_Improve_Verbal.15.aspx

Garzone, G., \& Viezzi, M. (2002). Interpreting in the 21st century: Challenges and opportunities (Vol. 43). John Benjamins Publishing.

Groves, R. M., Fowler Jr, F. J., Couper, M. P., Lepkowski, J. M., Singer, E., \& Tourangeau, R. (2011). Survey methodology (Vol. 561). John Wiley \& Sons.

Gunarto, M., \& Hurriyati, R. (2020). Creating Experience Value To Build Student Satisfaction In Higher Education. Dinasti International Journal of Education Management And Social Science, 1(3), 349-359.

Guskey, T. R. (2007). Multiple sources of evidence: An analysis of stakeholders' perceptions of various indicators of student learning. Educational Measurement: Issues and Practice, 26(1), 19-27. https://doi.org/10.1111/j.1745-3992.2007.00085.x

Harvey, L. (2000). New realities: The relationship between higher education and employment. Tertiary Education and Management, 6(1), 3-17. https://doi.org/10.1080/13583883.2000.9967007

Humburg, M., \& Van der Velden, R. (2015). Skills and the graduate recruitment process: Evidence from two discrete choice experiments. Economics of Education Review, 49, 24-41.

Husain, M. Y., Mokhtar, S. B., Ahmad, A. A., \& Mustapha, R. (2010). Importance of employability skills from employers' perspective. Procedia-Social and Behavioral Sciences, 7, 430-438.

Jagosh, J., Macaulay, A. C., Pluye, P., Salsberg, J. O. N., Bush, P. L., Henderson, J. I. M., Sirett, E., Wong, G., Cargo, M., \& Herbert, C. P. (2012). Uncovering the benefits of participatory research: Implications of a realist review for health research and practice. The Milbank Quarterly, 90(2), 311-346. https://doi.org/10.1111/j.14680009.2012.00665.x

Jamaluddin, D., Ramdhani, M. A., Priatna, T., \& Darmalaksana, W. (2019). Techno university to increase the quality of Islamic Higher Education in Indonesia. International Journal of Civil Engineering and Technology (IJCIET), 10(1), 12641273. 
Jayanti, S., Iskandar, I., \& Hayat, N. (2019). Analisis Kepuasan Pengguna Lulusan Terhadap Alumni Komunikasi dan Penyiaran Islam IAIN Parepare. JURNAL PENELITIAN, 13(2), 279-304.

Kavanagh, M. H., \& Drennan, L. (2008). What skills and attributes does an accounting graduate need? Evidence from student perceptions and employer expectations. Accounting \& Finance, 48(2), 279-300.

Kisworo, B., Utsman, U., Ilyas, I., \& Siswanto, Y. (2018). Kepuasan Mahasiswa dan Pengguna Lulusan Program Studi Pendidikan Luar Sekolah Universitas Negeri Semarang. Journal of Nonformal Education and Community Empowerment, 2(2).

Knight, P. T., \& Yorke, M. (2003). Employability and good learning in higher education. Teaching in Higher Education, 8(1), 3-16. https://doi.org/10.1080/1356251032000052294

Lohman, M. C. (2004). The development of a multirater instrument for assessing employee problem-solving skill. Human Resource Development Quarterly, 15(3), 303-321.

Mada, M., \& Ashar, K. (2015). Analisis variabel yang mempengaruhi jumlah pengangguran terdidik di Indonesia. Jurnal Ilmu Ekonomi Dan Pembangunan, 15(1). https://doi.org/10.20961/jiep.v15i1.9894

Markides, C. C., \& Williamson, P. J. (1994). Related diversification, core competences and corporate performance. Strategic Management Journal, 15(S2), 149-165. https://doi.org/10.1002/smj.4250151010

Martilla, J. A., \& James, J. C. (1977). Importance-performance analysis. Journal of Marketing, 41(1), 77-79.

Maryati, S. (2015). Dinamika pengangguran terdidik: Tantangan menuju bonus demografi di Indonesia. Economica: Jurnal Program Studi Pendidikan Ekonomi STKIP PGRI Sumatera Barat, 3(2), 124-136. http://DOI. 10.22202/economica.2015.v3.i2.249

Meñez, N. L. (2014). Tracer study of the Masters in Business Administration (MBA) graduates from 2008-2012. Asia Pacific Journal of Education, Arts and Sciences, 1(1), 14-18. http://research.lpubatangas.edu.ph/wp-content/uploads/2014/10/APJEASTracer-Study-of-MBA-Graduates.pdf

Momeni Mahmuee, H. (2009). Improvement of high education curriculum; a step toward training creative alumni. Educational Strategies, 2(3), 121-126. http://pdfarchive.ir/pack-15/Do_26313880309.pdf

Moreland, N. (2006). Entrepreneurship and higher education: An employability perspective (Vol. 6). Higher Education Academy York. http://hdl.voced.edu.au/10707/185826.

Much, K., Wagener, A. M., Breitkreutz, H. L., \& Hellenbrand, M. (2014). Working with the millennial generation: Challenges facing 21 st-century students from the perspective of university staff. Journal of College Counseling, 17(1), 37-47. https://doi.org/10.1002/j.2161-1882.2014.00046.x

Muzenda, A. (2013). Lecturers' competences and students' academic performance. International Journal of Humanities and Social Science Invention, 3(1), 6-13. 
Napitupulu, D., Rahim, R., Abdullah, D., Setiawan, M. I., Abdillah, L. A., Ahmar, A. S., Simarmata, J., Hidayat, R., Nurdiyanto, H., \& Pranolo, A. (2018). Analysis of student satisfaction toward quality of service facility. J. Phys. Conf. Ser, 954(1), 12019.

Nunnally, J. (1978). C.(1978). Psychometric Theory, 2, 1202-1208.

O'Brien, P. (2002). Making College Count: A Real World Look at How To Succeed in College. Ten Speed Press.

Olojuolawe, R. S., Amin, N. F., Latif, A. A., \& Arsat, M. (2019). Employability skills of higher education graduates: A review and integrative approach. TVET Towards Industrial Revolution 4.0: Proceedings of the Technical and Vocational Education and Training International Conference (TVETIC 2018), November 26-27, 2018, Johor Bahru, Malaysia, 113.

Peacock, N., \& Ladkin, A. (2002). Exploring relationships between higher education and industry: A case study of a university and the local tourism industry. Industry and Higher Education, 16(6), 393-401. https://doi.org/10.5367/000000002101296568

Peng, L., Zhang, S., \& Gu, J. (2016). Evaluating the competency mismatch between Master of Engineering graduates and industry needs in China. Studies in Higher Education, 41(3), 445-461. https://doi.org/10.1080/03075079.2014.942268

Pollock, P. H., Hamann, K., \& Wilson, B. M. (2011). Learning through discussions: Comparing the benefits of small-group and large-class settings. Journal of Political Science Education, 7(1), 48-64. https://doi.org/10.1080/15512169.2011.539913

Rafik, A., \& Priyono, A. (2018). A new insight into alumni satisfaction model for Islamic higher education institutions (IHEI). Management Research Review.

Ramli, A., Nawawi, R., \& Chun, M. P. P. (2010). Employees' perception of employability skills needed in todays workforce among physiotherapy graduates. Procedia-Social and Behavioral Sciences, 7, 455-463.

Ryan, G., Emmerling, R. J., \& Spencer, L. M. (2009). Distinguishing high-performing European executives: The role of emotional, social and cognitive competencies. Journal of Management Development, 28(9), 859-875. https://doi.org/10.1108/02621710910987692

Sasson Joseph R., \& Douglas Ian. (2006). A conceptual integration of performance analysis, knowledge management, and technology: From concept to prototype. Journal of Knowledge Management, 10(6), 81-99. https://doi.org/10.1108/13673270610709233

Scott, P. (2000). Globalisation and higher education: Challenges for the 21 st century. Journal of Studies in International Education, 4(1), 3-10. https://doi.org/10.1177/102831530000400102

Setyaningsih, I., \& Abrori, M. (2013). Analisis Kualitas Lulusan Berdasarkan Tingkat Kepuasan Pengguna Lulusan. Jurnal Ilmiah Teknik Industri, 12(1), 73-82.

Snyder, L. G., \& Snyder, M. J. (2008). Teaching critical thinking and problem solving skills. The Journal of Research in Business Education, 50(2), 90.

Soegoto, H. S., Wahdiniwaty, R., Warlina, L., \& Heryandi, A. (2018). E-tracer study implementation of Indonesia Computer University alumni. Journal of Educational Research and Reviews, 6(2), 38-46. 
Støren, L. A., \& Aamodt, P. O. (2010). The quality of higher education and employability of graduates. Quality in Higher Education, 16(3), 297-313. https://doi.org/10.1080/13538322.2010.506726

Suarta, I. M., Suwintana, I. K., Sudhana, I. F. P., \& Hariyanti, N. K. D. (2017). Employability skills required by the 21st century workplace: A literature review of labor market demand. International Conference on Technology and Vocational Teachers (ICTVT 2017). https://doi.org/10.2991/ictvt-17.2017.58

Suarta, I. M., Suwintana, I. K., Sudhana, I. F. P., \& Hariyanti, N. K. D. (2018). Employability skills for entry level workers: A content analysis of job advertisements in Indonesia. Journal of Technical Education and Training, 10(2).

Suleman, F. (2016). Employability skills of higher education graduates: Little consensus on a much-discussed subject. Procedia-Social and Behavioral Sciences, 228, 169-174.

Suleman, F. (2018). The employability skills of higher education graduates: Insights into conceptual frameworks and methodological options. Higher Education, 76(2), 263-278.

Tan, L. C., \& French-Arnold, E. (2012). Employability of graduates in Asia: An overview of case studies. Bangkok Asia and Pacific Regional Bureau for Education: UNESCO.

Teichler, U. (1999). Higher education policy and the world of work: Changing conditions and challenges. Higher Education Policy, 12(4), 285-312.

Teijeiro, M., Rungo, P., \& Freire, M. J. (2013). Graduate competencies and employability: The impact of matching firms' needs and personal attainments. Economics of Education Review, 34, 286-295.

Tinta, J. (2015). TRANSFORMASI PARADIGMA PENDIDIKAN ISLAM PASCA REFORMASI. https://aqienzziant.wordpress.com/2015/12/12/transformasi-paradigmapendidikan-islam-pasca-reformasi/

Trinder, J. C. (2008). Competency Standards-a Measure of the Quality of a Workforce. ISPRS XXI International Congress, Beijing, China.

UIN Malang. (2018a). Laporan Wisuda Program Diprolga Tiga, Sarjana dan Pascasarjana 2017/2018. UIN Press.

UIN Malang. (2018b). Pedoman Pendidikan Universitas Islam Negeri Maulana Malik Ibrahim Malang. UIN Press.

Unesco, Bangkok. A. and P. R. B. for E. (2012). Graduate employability in Asia. https://www.voced.edu.au/content/ngv:50738

Velasco, M. S. (2012). More than just good grades: Candidates' perceptions about the skills and attributes employers seek in new graduates. Journal of Business Economics and Management, 13(3), 499-517.

Wrahatnolo, T. (2018). 21st centuries skill implication on educational system. IOP Conference Series: Materials Science and Engineering, 296(1), 012036. 